\title{
SPECIES DISTINCTNESS OF SADLERIANA ROBICI (CLESSIN, 1890) (GASTROPODA: RISSOOIDEA)
}

\author{
MAGDALENA SZAROWSKA, ANDRZEJ FALNIOWSKI
}

\begin{abstract}
Department of Malacology, Institute of Zoology, Jagiellonian University, Gronostajowa 9, 30-387 Cracow, Poland (e-mail: andrzej.falniowski@uj.edu.pl)

ABSTRACT: Partial sequences of cytochrome oxidase subunit I (COI) gene were studied in four populations of Sadleriana Clessin, 1890 from Slovenia and Croatia. All study localities were within the distribution range of $S$. fluminensis (Küster, 1852); one was the type locality of S. robici (Clessin, 1890), at which S. robici co-occurred with $S$. fluminensis. No significant differences were found in the genital characters of all the congeners. There were significant differences in shell characters between the syntopic S. robici and S. fluminensis. The molecular characters indicated relatively high differences (K2P distances about 0.03 ) among the populations of $S$. fluminensis, not corresponding with the shell habitus and dimensions. The highest differences (K2P distances about 0.07 ) were found between the syntopic S. fluminensis and S. robici specimens, which verifies species distinctness of these two lineages.
\end{abstract}

KEY WORDS: cytochrome oxidase subunit I, K2P distance, Balkans, mtDNA

\section{INTRODUCTION}

Representatives of Sadleriana Clessin, 1890, with the type species $S$. fluminensis (Küster, 1852), inhabit springs and rivers in Slovenia and Croatia (RADOMAN 1985, KABAT \& HERSHLER 1993, SZAROWSKA 2006); apart from the Balkans one Sadleriana species is known from Bavaria in Germany (SZAROWSKA \& WILKE 2004). The genus was revised by RADOMAN (1967) and BOLE (1972). According to RADOMAN (1983), there are six species of Sadleriana in the Balkans: S. fluminensis, S. sadleriana (Frauenfeld, 1863), S. robici (Clessin, 1890), S. supercarinata (Schütt, 1969), S. schmidti (Menke, 1850) and S. cavernosa Radoman, 1978 (the latter two subterranean). The nominal species listed above are distinguished based on the shell alone. In some cases their interspecific differences are weakly marked, like those between S. fluminensis and S. sadleriana, which differ only in shell size (RADOMAN 1983). In others, like $S$. cavernosa or $S$. robici, there are well-marked differences in shell morphology. In the latter, the shell is ovate-conical and resembles Bythinella. CLESSIN (1887-1890) described it as Bythinella robici. Interestingly, in the same monograph he confused a Bythinella with a neritiform shell for Lithoglyphus section Sadleriana, and described it as
Lithoglyphus (Sadleriana) pannonica Clessin, 1890 (SZAROWSKA \& WILKE 2004). It is widely known that the shell is not sufficient for species distinction within the Rissooidea, Adriohydrobia Radoman, 1973 being a good example. Within that genus three nominal species were described based on a distinct shell habitus of each: A. gagatinella (Küster, 1852), A. kutschigi (Küster, 1853), and A. consociella (Frauenfeld, 1863), but according to molecular data (WILKE \& FALNIOWSKI 2001) all three taxa belong to one species, $A$. gagatinella. Even if two morphotypes are found at one locality they may not represent distinct species but only different generations that differ in shell morphology (FALNIOWSKI et al. 2012: Radomaniola).

As noted above, two species of Sadleriana are subterranean, known only from the type localities; $S$. supercarinata was found within a very restricted range in Gacko polje, Croatia (RADOMAN 1983). Of the other three, S. fluminensis is widely distributed in Slovenia and Croatia. In 2004 PÉTER SólYMOS recorded it in Serbia (Fruska Gora Mountains, P. SólYMOS pers. comm.). According to RADOMAN (1983) in part of its range it may be found together with $S$. sadleriana (the drainage areas of the Sava and 
Ljubljanica rivers) and S. robici (the Krka River drainage area).

CLESSIN (1887-1890) gives the type locality of $S$. robici as the source of the Krka River. The main source of the river is situated in the cave Jama Krke. During our field collection in Slovenia and Croatia (4-10 June 2011) the cave was not accessible due to the huge outflow. However, in the source area of the Krka River, about $300 \mathrm{~m}$ from the main source, we found a smaller spring with two syntopic morphotypes of
Sadleriana. Thus we regarded the smaller, high-spired specimens as topotypical $S$. robici.

Having two sympatric congeners from the type locality of one of them (S. robici) we found it interesting to verify the species distinctness of $S$. fluminensis and $S$. robici using molecular data. We included also specimens from the type locality of $S$. fluminensis and from two other localities that represented different parts of the species range (different river systems).

\section{MATERIAL AND METHODS}

The material was collected on 4-10 June 2011. Using a sieve, about thirty specimens of Sadleriana were collected from each of the four localities (Fig. $1)$ :

1. Močilnik, the huge spring of the Ljubljanica River, Slovenia, $45^{\circ} 57^{\prime} 15^{\prime \prime} \mathrm{N}, 14^{\circ} 17^{\prime} 33^{\prime \prime E}, 313 \mathrm{~m}$ a.s.l., type locality of Sadleriana fluminensis (Küster, 1852);

2. the Sava River, Slovenia, $46^{\circ} 10^{\prime} 24.4^{\prime \prime} \mathrm{N}$, $14^{\circ} 24^{\prime} 54.2^{\prime \prime E}, 321 \mathrm{~m}$ a.s.1.;

3. a spring in the source area of the Krka River, $300 \mathrm{~m}$ from the main source, Slovenia, $45^{\circ} 53^{\prime} 11.8^{\prime \prime} \mathrm{N}$, $14^{\circ} 46^{\prime} 06.1^{\prime \prime E}, 312 \mathrm{~m}$ a.s.1., type locality of $\mathrm{S}$. robici (Clessin, 1890);

4. the Zrmanja River, near Radmilovići, Croatia, $44^{\circ} 11^{\prime} 48.6^{\prime \prime} \mathrm{N}, 15^{\circ} 46^{\prime} 04.6^{\prime \prime} \mathrm{E}, 11 \mathrm{~m}$ a.s.1.

Snails were washed twice in $80 \%$ ethanol and left to stand in it for around 12 hours. Then the ethanol was changed twice more within 24 hours and finally, after a few days, the $80 \%$ solution was replaced with a $96 \%$ one, in which the samples were stored at $-20^{\circ} \mathrm{C}$.

For the morphological study we cleaned the snail shells in an ultrasonic cleaner and photographed

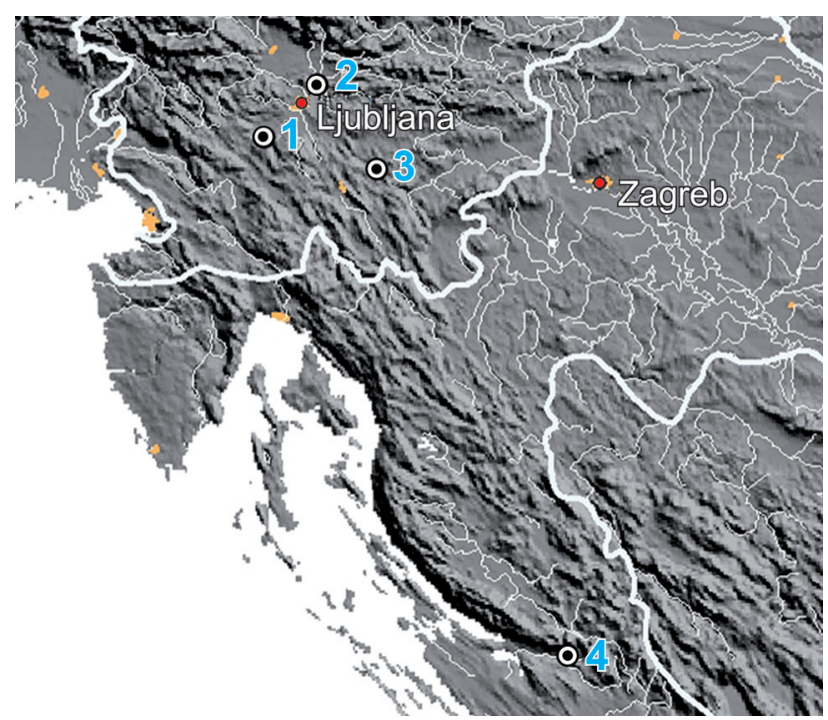

Fig. 1. Studied localities: 1 - Močilnik spring, 2 - Sava River, 3 - Krka River source, 4 - Zrmanja River; thick white lines represent country boundaries them with a CANON EOS 50D digital camera. From each population two males and two females were dissected using a NIKON SMZ-U stereomicroscope.

DNA was extracted from foot tissue of each snail. The tissue was hydrated in TE buffer $(10 \mathrm{mM}$ TRIS-HCl pH 8.0, 1 mM EDTA) $(3 \times 10$ min. $)$; then total genomic DNA was extracted with the SHERLOCK extracting kit (A\&A Biotechnology), and the final product was dissolved in $20 \mu \mathrm{l}$ TE buffer (the same concentration as used for hydration). The PCR reaction was performed with the following primers: LCO1490 (5'-GGTCAACAAATCATAAAGATATT GG-3') (FOLMER et al. 1994) and COR722b (5'-TAAACTTCAGGGTGACCAAAAAATYA-3') (WILKE \& DAVIS 2000) for the cytochrome oxidase subunit I (COI) mitochondrial gene. The PCR conditions were as follows: initial denaturation step of 4 min at $94^{\circ} \mathrm{C}$, followed by 35 cycles of $1 \mathrm{~min}$ at $94^{\circ} \mathrm{C}, 1$ $\min$ at $55^{\circ} \mathrm{C} 2 \mathrm{~min}$ at $72^{\circ} \mathrm{C}$, and a final extension of 4 min at $72^{\circ} \mathrm{C}$. The total volume of each PCR reaction mixture was $50 \mu \mathrm{l}$. To check the quality of the PCR products $10 \mu \mathrm{l}$ of the PCR product was run on $1 \%$ agarose gel. The PCR products were purified using Clean-Up columns (A\&A Biotechnology) and the purified PCR products were amplified in both directions (HILlis et al. 1996) using BigDye Terminator v3.1 (Applied Biosystems), following the manufacturer's protocol and with the primers described above. The sequencing reaction products were purified using ExTerminator Columns (A\&A Biotechnology); DNA sequences then underwent electrophoresis on an ABI Prism sequencer. All the sequences were deposited in GenBank (GenBank Accession numbers: KF193067-KF193085).

The COI sequences were aligned by eye and edited using BioEdit 5.0.0 (HALL 1999). K2P (KIMURA 1980) and p- genetic distances were calculated with MEGA4 (TAMURA et al. 2007). MEGA4 was also applied to phylogeny reconstruction with minimum-evolution approach (SWOFFORD et al. 1996, NEI \& KUMAR 2000) and K2P distances. Nodal support was estimated using the bootstrap approach (FELSENSTEIN 1985) with 10,000 replicates. 


\section{RESULTS}

The shells of the studied Sadleriana (Figs 2-11) varied in habitus and size between populations. At the type locality of $S$. robici the big-shelled, low-spired specimens (presumably S. fluminensis: Figs 2-3) co-oc-
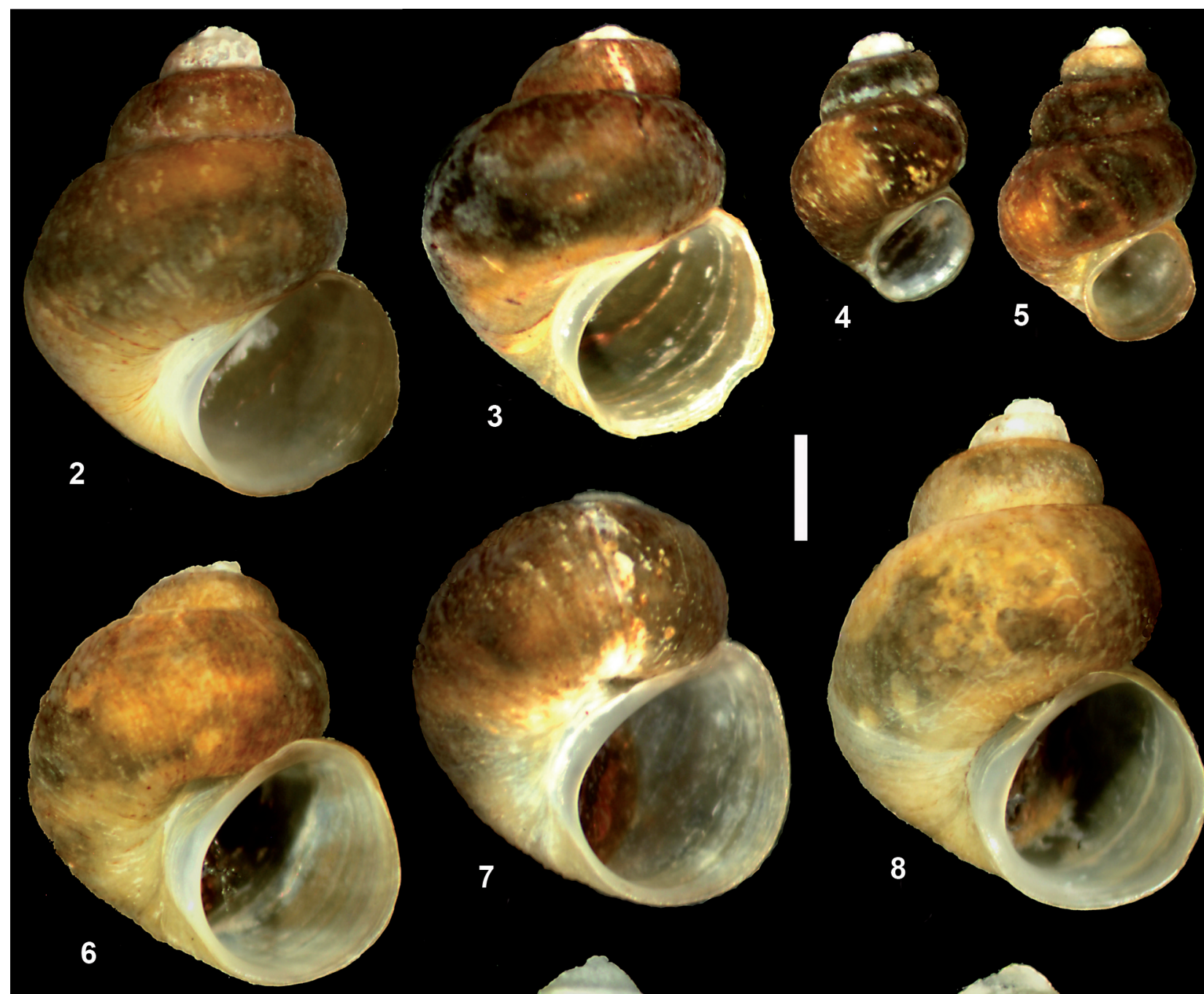

3
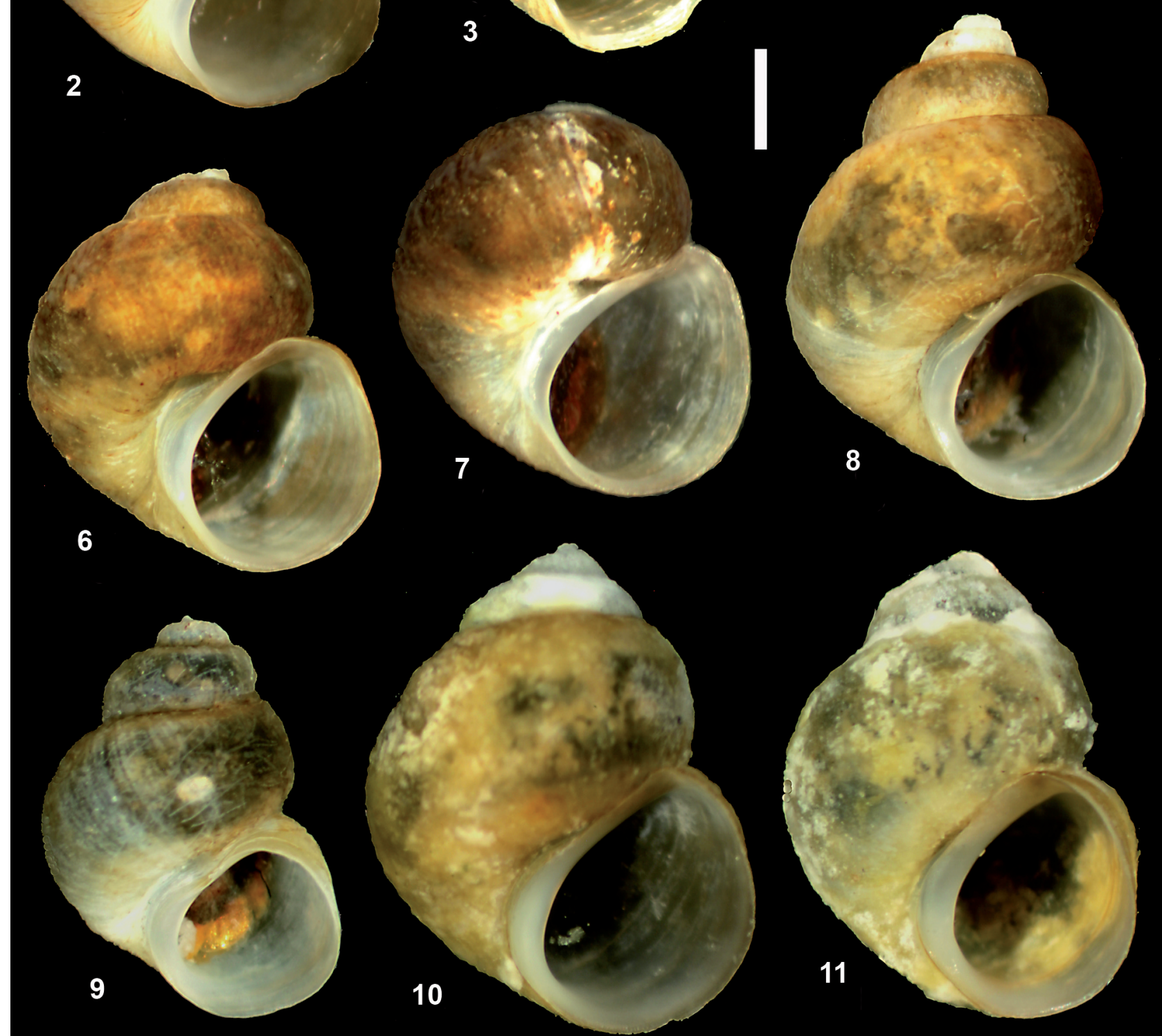

7
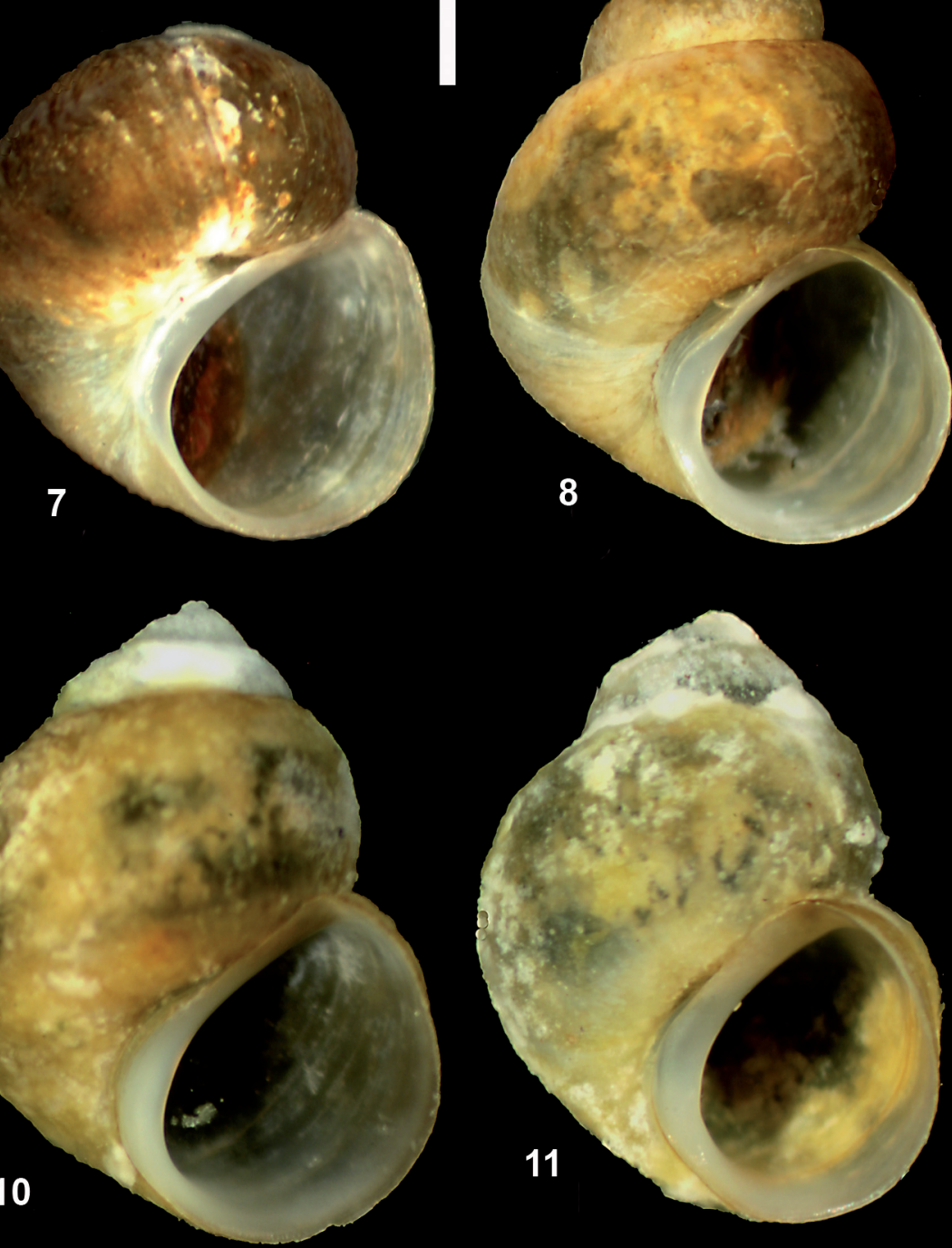

Figs 2-11. Shells of Sadleriana: 2-3 - S. fluminensis, locality 3 (Krka source), 4-5 - S. robici, locality 3 (Krka source); 6-11 - S. fluminensis: 6-7 - locality 1 (Močilnik), 8-9 - locality 2 (Sava), 10-11- locality 4 (Zrmanja); bar represents $0.5 \mathrm{~mm}$ 


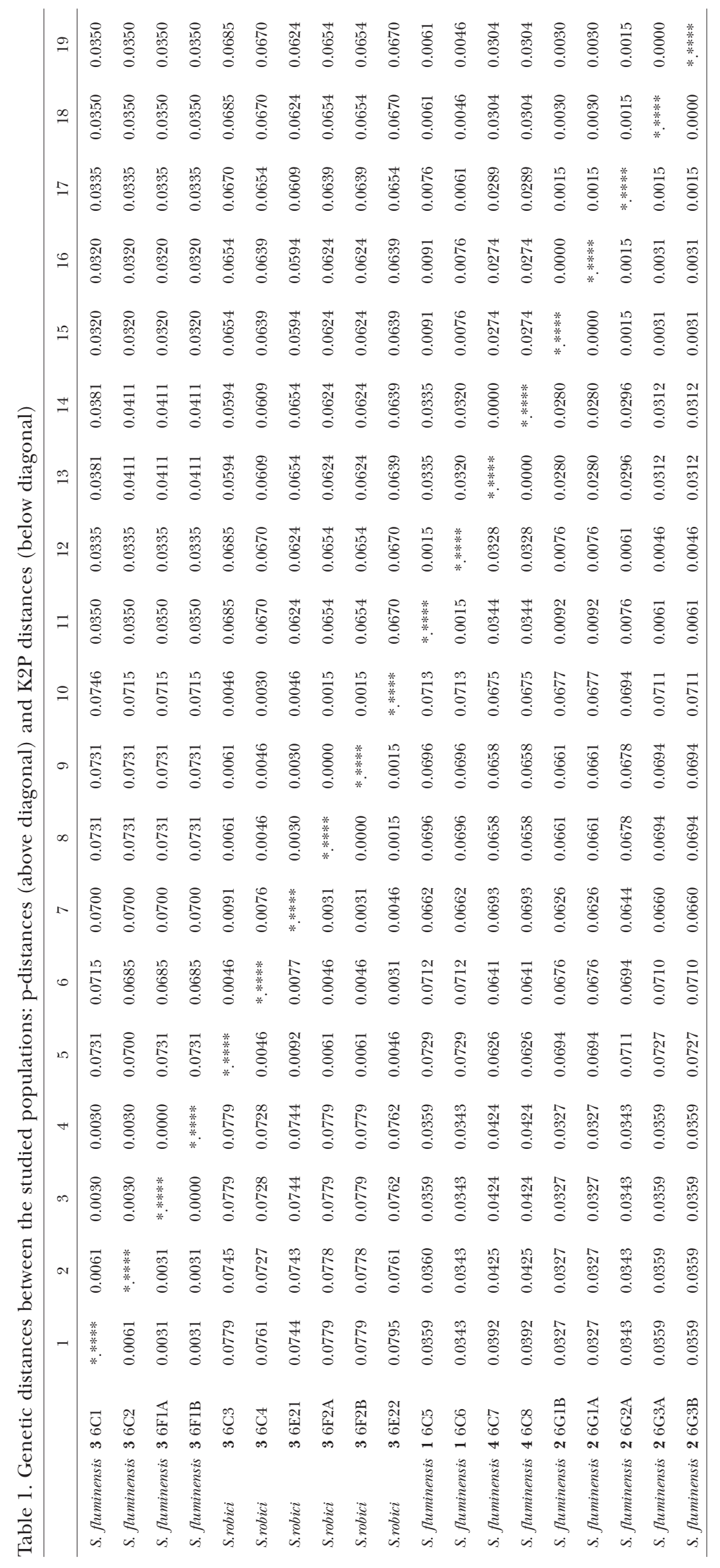




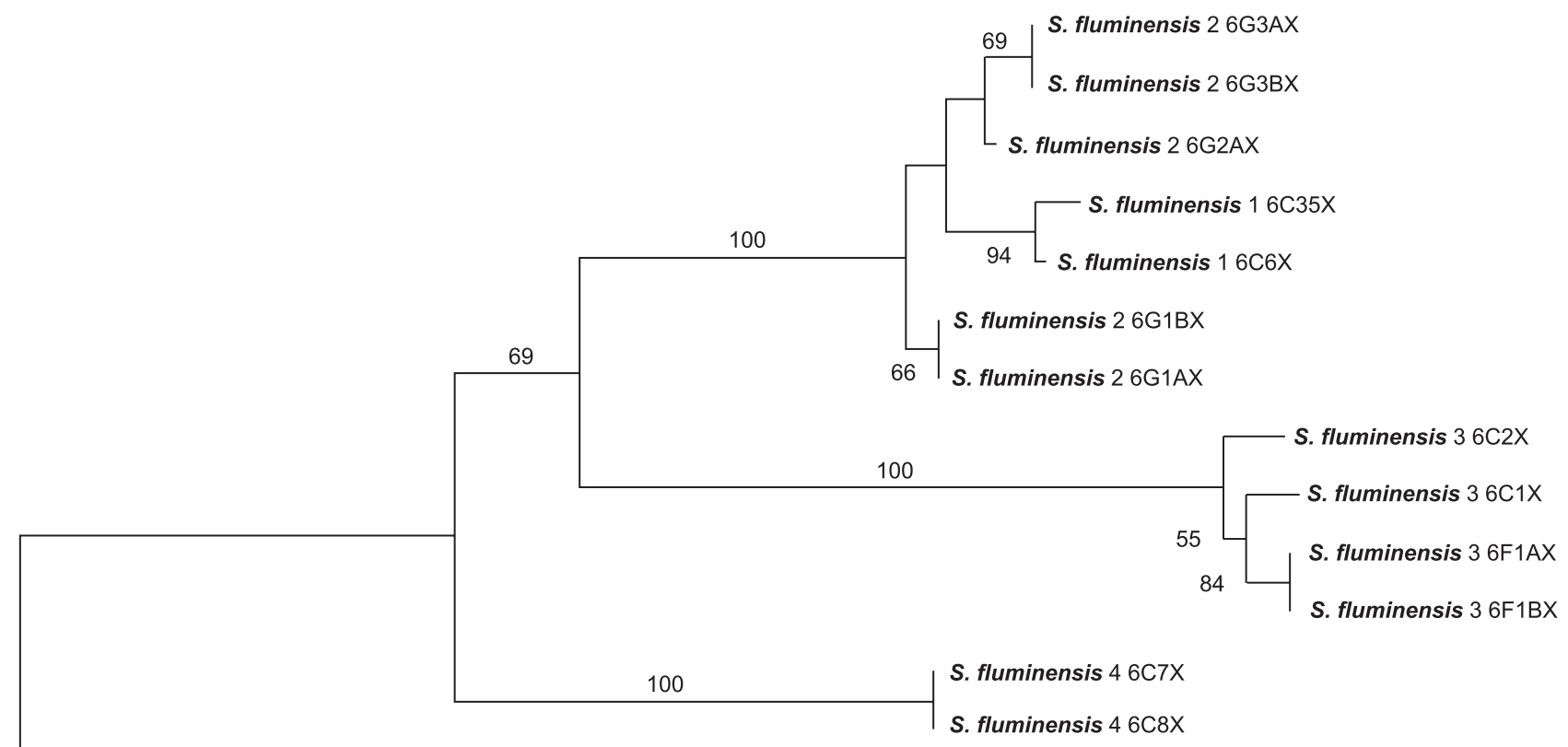

S. fluminensis $46 \mathrm{C} 8 \mathrm{X}$

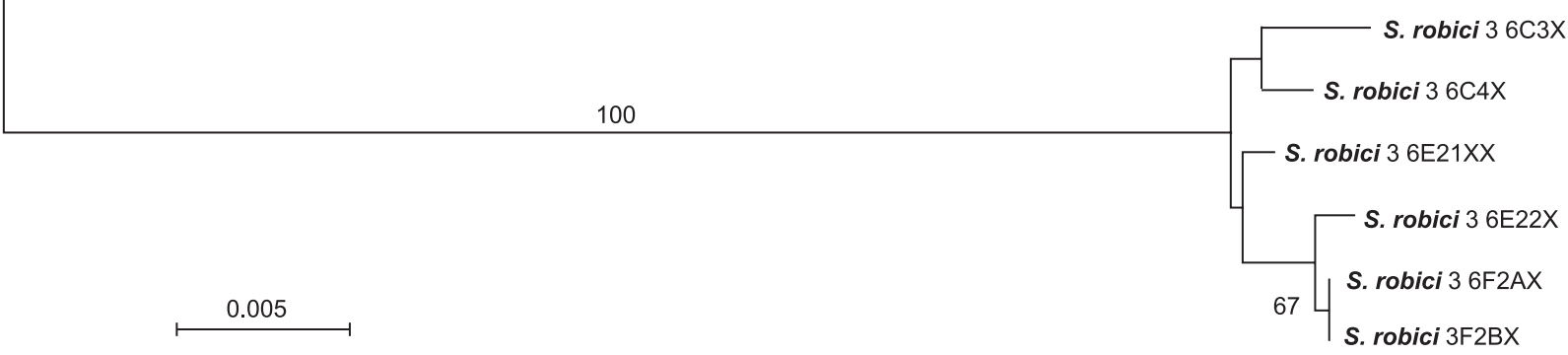

Fig. 12. Minimum-evolution tree computed with maximum composite likelihood distances; bootstrap supports given if $>50 \%$

curred with the small-shelled and high-spired ones ( $S$. robici: Figs 4-5). The shells from the other three localities, although varied in size and spire height (Figs 6-11), were all much bigger and lower-spired than the shells of S. robici. We have not found any differences in the genital anatomy among all the populations.

Genetic p- and K2P distances are presented in Table 1 . The highest values (about 0.07 ) are between $S$. robici and the other populations; the distances among the other Sadleriana (not S. robici) populations are lower by about half (except for $<0.01$ between 1 and 2). Minimum evolution tree based on composite

\section{DISCUSSION}

The S. robici specimens were molecularly distinct from all the other studied specimens (including the syntopic $S$. fluminensis from locality 3). K2P distances between $S$. robici and S. fluminensis (about 0.07) in the Rissooidea fall within the zone characteristic either of weakly marked interspecific values or high intraspecific variation, but rather characterise interspecific values (e.g. PEREZ et al. 2005, FALNIOWSKI et al. 2007, SZAROWSKA et al. 2007, FALNIOWSKI \& SZAROWSKA 2011). BICHAIN et al. (2007) reported the threshold likelihood distance (Fig. 12) shows the specimens from Močilnik (locality 1 ) and the Sava River (locality 2) mixed in one highly supported (bootstrap support $100 \%$ ) clade, belonging to a lower supported (69\%) clade with the large specimens ( $S$. fluminensis) from locality 3 (the type locality of $S$. robici). The topotypical $S$. robici population forms a highly supported $(100 \%)$ sister clade of all the other populations. The $S$. robici haplotypes are more distant from the sympatric S. fluminensis ones than from the geographically farthest $S$. fluminensis population from the Zrmanja River.

value 0.015 in the west-European Bythinella species. The $7 \%$ distance, the sympatric occurrence and the significant differences in shell characters considered, should be interpreted as interspecific. Thus, our data confirm that $S$. robici is a distinct species.

The other studied populations most probably represented $S$. fluminensis. Our molecular data show that this most widely distributed Sadleriana species is genetically rather highly differentiated. Molecularly the population from the Zrmanja River was distant from 
the ones from either Močilnik or the Sava River, and the S. fluminensis population from the Krka source area (locality 3) was situated between the ones from Močilnik, the Sava River and the Zrmanja River.

The well-marked differences in shell habitus and size between populations from Močilnik (Figs 6-7) and the Sava River (Figs 8-9) were coupled with small molecular differences between those two populations (two specimens from Močilnik clustering within five specimens from the Sava). In shell size, the topotypical specimens of $S$. fluminensis from Močilnik seem to resemble $S$. sadleriana. It is clear that shell characters cannot be sufficient for species distinction between the latter and $S$. fluminensis. This distinction is another question, not studied in this paper. On the other hand, the specimens from the Zrmanja River

\section{REFERENCES}

Bichain J.-M., GAUbert P., SAMAdi S., Boisselier-DUbayle M.-C. 2007. A gleam in the dark: Phylogenetic species delimitation in the confusing spring-snail genus Bythinella Moquin-Tandon, 1856 (Gastropoda: Rissooidea: Amnicolidae). Mol. Phyl. Evol. 45: 927-941.

http://dx.doi.org/10.1016/j.ympev.2007.07.018

BOLE J. 1972. Taksonomija i zoogeografija rodu Sadleriana Clessin, 1890 (Gastropoda, Prosobranchia)/Taxonomie und Zoogeographie der Gattung Sadleriana Clessin, 1890 (Gastropoda, Prosobranchia). Razprave, Slovenska Akademija Znanosti i Umetnosti, Razred za Rrirodoslovne i Medicinske Vede, Ljubljana 15: 49-74.

CLESSIN S. 1887-1890. Die Mollusken-Fauna Mitteleuropas, II. Theil: Die Molluskenfauna Österreich-Ungarns und der Schweiz. Bauer und Raspe, Nürnberg.

FALNIOWSKI A., SZAROWSKA M. 2011. Radiation and phylogeography in a spring snail Bythinella (Mollusca: Gastropoda: Rissooidea) in continental Greece. Ann. Zool. Fenn. 48: 67-90.

http:/ /dx.doi.org/10.5735/086.048.0201

Falniowski A., SZAROWSKa M., GlÖer P., PeŠIĆ V. 2012. Molecules vs morphology in the taxonomy of Radomaniola/Grossuana group of the Balkan Rissooidea (Mollusca, Caenogastropoda). J. Conch. 41: 19-36.

FAlNiOWSKI A., SZAROWSKA M., GRZMIL P. 2007. Daphniola Radoman, 1973 (Gastropoda: Hydrobiidae): shell biometry, mtDNA, and the Pliocene flooding. J. Nat. Hist. 41: 2301-2311.

http://dx.doi.org/10.1080/00222930701630733

FELSENSTEIN J. 1985. Confidence limits on phylogenies: an approach using the bootstrap. Evolution 39: 783-791. http:/ /dx.doi.org/10.2307/2408678

FOLMER O., Black M., HOEH W., LUtZ R. A., VRIJENHOEK R. C. 1994. DNA primers for amplification of mitochondrial cytochrome c oxidase subunit I from diverse metazoan invertebrates. Mol. Mar. Biol. Biotechnol. 3: 294-299.
(Figs 10-11) located far from the other (Slovenian) localities, morphologically resembled the specimens from the Sava River and not the ones from Močilnik. Considering the conchological and genital similarities and the level of genetic distance among the studied S. fluminensis populations the Zrmanja population also belongs to $S$. fluminensis.

\section{ACKNOWLEDGEMENTS}

We thank an anonymous reviewer for providing us with new data on the distribution of S. fluminensis and for valuable comments on the manuscript. The study was supported by a grant from the National Science Centre $(2011 / 01 / \mathrm{B} / \mathrm{NZ} 8 / 01721)$ to ANDRZEJ FALNIOWSKI.

HALL T. A. 1999. BioEdit: a user-friendly biological sequence alignment editor and analysis program for Windows 95/98/NT. Nucl. Acids Symp. Ser. 41: 95-98.

Hillis D. M., Mable B. K., LARSOn A., DAVIS S. K., Zimmer E. A. 1996. Nucleic acids IV: sequencing and cloning. In: Hillis D. M., Moritz C., MABle B. K. (eds), Molecular systematics, 2 ed., Sinauer Associates, Inc., Sunderland, Massachusetts, pp. 321-381.

KABAT A. R., HERSHLER R. 1993. The prosobranch snail family hydrobiidae (Gastropoda: Rissooidea): review of classification and supraspecific taxa. Smithsonian Contrib. Zool. 547: 1-94.

http://dx.doi.org/10.5479/si.00810282.547

KIMURA M. 1980. A simple method for estimating evolutionary rate of base substitutions through comparative studies of nucleotide sequences. J. Mol. Evol. 16: 111-120. http://dx.doi.org/10.1007/BF01731581

NEI M., KUMAR S. 2000. Molecular evolution and phylogenetics. Oxford University Press, Oxford.

Perez K. E., Ponder W. F., Colgan D. J., Clark S. A., LYDEARD C. 2005. Molecular phylogeny and biogeography of spring-associated hydrobiid snails of the Great Artesian Basin, Australia. Mol. Phyl. Evol. 34: 545-556. http://dx.doi.org/10.1016/j.ympev.2004.11.020

RADOMAN P. 1967. Das Genus Sadleriana. Glasnik Prirodnjackog Museja, Beograd series B 20: 121-126.

RADOMAN P. 1983. Hydrobioidea a superfamily of Prosobranchia (Gastropoda). I Systematics. Serbian Academy of Sciences and Arts, Monographs 547, Department of Sciences 57: 1-256.

RADOMAN P. 1985. Hydrobioidea, a superfamily of Prosobranchia (Gastropoda). II. Origin, zoogeography, evolution in the Balkans and Asia Minor. Faculty of Science-Department of Biology Monograph, 1, Institute of Zoology Beograd 1: 1-173.

SWOFFord D. L., Olsen G. J., WAdDell P. J., Hillis D. M. 1996. Phylogenetic inference. In: Hillis D. M., MORITZ C., Mable B. K. (eds), Molecular systematics, 2 ed., 
Sinauer Associates, Inc., Sunderland, Massachusetts, pp. 407-514.

SZAROWSKA M. 2006. Molecular phylogeny, systematics and morphological character evolution in the Balkan Rissooidea (Caenogastropoda). Folia Malacol. 14: 99-168.

SZarowska M., Grzmil P., FAlniowski A., Sirbu I. 2007. Grossuana codreanui (Grossu, 1946) and the phylogenetic relationships of the East Balkan genus Grossuana (Radoman, 1973) (Gastropoda: Rissooidea). Hydrobiologia 579: 379-391.

http://dx.doi.org/10.1007/s10750-006-0530-4

SZAROWSKA M., Wilke T. 2004. Sadleriana pannonica (Frauenfeld, 1865): a lithoglyphid, hydrobiid or amnicolid taxon? J. Moll. Stud. 70: 49-57. http://dx.doi.org/10.1093/mollus/70.1.49

TAMURA K., DUdley J., NeI M., Kumar S. 2007. MEGA4: Molecular Evolutionary Genetics Analysis (MEGA) software version 4.0. Mol. Biol. Evol. 24: 1596-1599. http://dx.doi.org/10.1093/molbev/msm092

WILKE T., DAVIS G. M. 2000. Infraspecific mitochondrial sequence diversity in Hydrobia ulvae and Hydrobia ventrosa (Hydrobiidae: Rissoacea: Gastropoda): Do their different life histories affect biogeographic patterns and gene flow? Biol. J. Linn. Soc. London 70: 89-105. http://dx.doi.org/10.1111/j.1095-8312.2000.tb00202.x

Wilke T., FALniowski A. 2001. The genus Adriohydrobia (Hydrobiidae: Gastropoda): polytypic species or polymorphic populations? J. Zool. Syst. Evol. Res. 39: 227-234.

http://dx.doi.org/10.1046/j.1439-0469.2001.00171.x

Received: November 11th, 2012

Revised: January 9th, 2013

Accepted: January 15th, 2013 